\title{
Faculty Perspectives on Undergraduate Research Skills Nine Core Skills for Research Success
}

\author{
Boglarka S. Huddleston, \\ Jeffrey D. Bond, \\ Linda L. Chenoweth, and \\ Tracy L. Hull \\ Boglarka S. Huddleston \\ (b.huddleston@tcu.edu) is the Health \\ Sciences \& Assessment Librarian \\ at Texas Christian University. \\ Jeffrey D. Bond (j.bond@tcu.edu) \\ is the Scholarly Communication \\ Librarian and Science Research \\ Liaison at Texas Christian University.
}

Reference \& User Services Quarterly, vol. 59, no. 2, pp. 118-30

(c) 2019 American Library Association. All rights reserved.

Permission granted to reproduce for nonprofit, educational use.
In an effort to improve information literacy initiatives at Texas Christian University, we sought to understand faculty members' expectations and perceptions of undergraduate student research skills. We conducted three faculty focus groups $(n=21)$ and an online survey $(n=100)$ of faculty members. This study reveals a set of nine core research skills that faculty members expect students to possess. The study compares faculty members' expectations against their perceptions of student capability for each of these nine core skills. Furthermore, this study examines who (librarians, faculty, or both) should have responsibility for teaching which research skills. These findings will inform the library's information literacy initiatives, as well as have a strong influence on the library's marketing and reference services.

T

exas Christian University (TCU) in Fort Worth is a private university with a total current full-time enrollment of 10,782 and an undergraduate fulltime enrollment of 9,261. There are 1,220 to 2,300 undergraduates each in Business, Communication, Liberal Arts, Nursing and Allied Health Sciences, and Science and Engineering. Fine Arts and Education have smaller enrollments. ${ }^{1}$ As librarians at TCU, we wanted to learn more from the faculty to better understand which research skills they perceive to be most important for undergraduate students to possess and further understand their perceptions of students' aptitudes related to those skills. This study will inform our information literacy programming and may open up collaborations with faculty members as we identify new approaches to improve undergraduate research skills.

The term information literacy (IL) was coined by Paul Zurkowski in 1974 . $^{2}$ Since that time, IL has increasingly been a staple component of academic libraries. Its emphasis has evolved and broadened over the years from focusing on basic skills, such as finding information, to including concepts like topic selection, evaluating sources, and understanding ethical use of information.

The methods of instruction have also evolved over the years and can vary depending on the situation. Librarians have used a plethora of methods, including but not limited to one-shot instruction sessions, library tours, scavenger hunts, and being embedded into course management systems (CMS). Regardless of the method, it can be difficult for librarians to fully understand how well students learn and practice research skills and how their competency compares to faculty 
expectations. Librarians sometimes have discussions with faculty members about assignments or gaps in research skills; however, these discussions are often quick, happen via e-mail, and only scratch the surface of what the faculty members believe is missing in their students' skillsets.

\section{LITERATURE REVIEW}

Academic librarians have long been interested in the definition and dimensions of information literacy. In 2000, the Association of College and Research Libraries (ACRL) published the Information Literacy Competency Standards for Higher Education, which defined IL as the ability to recognize when information is needed and then find, evaluate, and use information effectively. ${ }^{3}$ In 2016, the ACRL adopted the Framework for Information Literacy for Higher Education, which recognized that in a rapidly changing information and educational environment, the concept of IL had become a more complex, interconnected set of ideas. The Framework encourages librarians and faculty members to collaborate more effectively on assignments and to connect studentlearning outcomes with IL concepts. ${ }^{4}$ These IL concepts provide a basis for many library instruction classes. However, better overall curriculum integration and scaffolding require faculty support and an understanding of how these skills are transferable across departments and fields of research.

\section{Models of Information Searching Behaviors}

Librarians are also interested in information searching behaviors and how these behaviors relate to the learning process. Understanding how users look for and use resources informs the way librarians interact with students either in a classroom or in a one-on-one setting. Several models of information searching behaviors exist in the literature. Carol Kuhlthau's classic Information Search Process model focuses on three components: the affective, the cognitive, and the physical aspects of information searching. Students move through six stages from "initiation" to "presentation" as they complete research assignments. The point of intervention by a librarian should be at the student's highest level of uncertainty. ${ }^{5}$ Christine Bruce's Seven Faces of Information Literacy claims that IL "may be described as a complex of the different ways in which it appears to people/is seen, experienced or understood." Each "face" consists of elements of information technology, information use, and one of seven unique elements such as information sources or information control. ${ }^{7}$ Eisenberg and Berkowitz developed the Big6 Model, which takes a systematic approach to information problem-solving at any stage of life. The six stages each contain an information skill and technology skills, and together they form a process to help students learn problem solving. The stages are flexible, and it is not necessary to complete them in order; however, all must be completed to achieve success in information problem-solving. ${ }^{8}$ These three models describe how students search for and make use of information, as well as the cognitive processes involved in this activity. Librarians who are familiar with basic models of information seeking behaviors can design instruction that considers both student behavior and the skills to be taught.

\section{Faculty Views of Information Literacy}

Studies show that when faculty members are asked about the importance of IL skills, they generally agree that these skills are valuable and that students should possess them by the time they graduate. Eleonora Dubicki found that faculty members were familiar with IL concepts and incorporated them into student learning outcomes. Faculty members thought that ACRL Standard 3, which refers to evaluating information and its sources critically, was the most important standard skill to possess. However, faculty member perception was that students did not master IL skills by graduation. Faculty perceived students to be most skilled at identifying an information need and least skilled at "evaluating and critically assessing the information." Jonathan Cope and Jesús Sanabria interviewed faculty members about their notions of IL and found that faculty had addressed basic literacies with students, especially literacies that related to skills such as reading comprehension, vocabulary, and writing. The interviews also revealed that the notion of IL was not influenced by discipline. ${ }^{10}$ Keith Stanger surveyed psychology faculty about the importance of ACRL's psychology IL performance indicators being part of the curriculum and found that ten out of the eleven indicators (ranging from need for information to communicating research effectively) were of great or very great importance. ${ }^{11}$ Laura Saunders also concluded that "faculty members overwhelmingly believe that information literacy is important for their students." ${ }^{2}$ Yevelson-Shorsher and Bronstein's interviews with faculty revealed that faculty members were aware of the obstacles students face when accessing and using information, and faculty understood the significance of developing IL skills. ${ }^{13}$

\section{Faculty Views of Student Research Skills}

Multiple studies surveying university faculty show that they think their students do not have well-developed research skills; however, faculty members see some improvement from freshmen to more advanced students. A faculty survey conducted by Patricia Meer, Maria Perez-Stable, and Dianna Sachs showed that faculty members rated their undergraduate students' ability to find information via library resources or the internet as below satisfactory. Juniors and seniors showed some improvement in using the internet yet remained below satisfactory in using library resources. ${ }^{14}$ Sophie Bury's survey revealed that faculty members perceived a gradual improvement in IL competencies from freshmen to graduate-level students' research work. She also noted that "students rely too much on the free Web for information, a behaviour pattern that is compounded 


\section{FEATURE}

by students' overreliance on Google. It is challenging to get students to move beyond this."15 In 2016, Bury found that students' critical thinking skills, source evaluation, and topic formulation skills were all main concerns for faculty. ${ }^{16}$ Shelley Gullikson determined that understanding plagiarism, reading comprehension, and critical thinking were among the highest rated desired outcomes. ${ }^{17}$ The 2015 Ithaka S+R US Faculty Survey indicated that "fifty-four percent of respondents strongly agreed that their undergraduate students have "poor skills related to locating and evaluating scholarly information."'18 Heather Perry's semi-structured interviews with faculty found that the two main areas where student research skills fell short were selecting appropriate or sufficiently rigorous materials and differentiating primary and secondary sources. ${ }^{19}$

\section{Collaborative Teaching Relationships}

Research suggests some disagreement on who should be responsible for teaching IL skills and when they should be taught. Wu and Kendall discovered that business faculty members had expectations of students developing library research skills and an awareness of issues of plagiarism. Faculty also indicated that the two main requests they have of librarians are to conduct an overall orientation to library resources and to provide the necessary tools for research. ${ }^{20}$ Gullikson listed student learning outcomes that librarians were responsible for teaching, including topic exploration, describing information needs, source evaluation, and appropriate citation. ${ }^{21}$ Gloria Leckie and Anne Fullerton found that many faculty members were teaching various aspects of IL and critical thinking skills in their classes yet had not taken advantage of library instructional services. ${ }^{22}$ Saunders did not find a clear answer to the question of who should be responsible for teaching IL concepts. ${ }^{23}$ William Badke reviewed the many barriers librarians encounter when attempting to share teaching responsibilities with faculty. ${ }^{24}$

Faculty members' perceptions of the librarian's role in instruction has evolved in the last thirty years. In 1987, Gaby Divay, Ada Ducas and Nicole Michaud-Oystryk found that helping with research and providing information about changes in the library were the top two most important functions of a librarian, while assistance in teaching was ranked lower. They also found that faculty members had low expectations of librarians and had a general lack of knowledge of the librarian's responsibilities. ${ }^{25}$ In 2004, Ducas and Michaud-Oystryk surveyed librarians who reported that faculty members looked to them for collection development, information services, technology, and lastly as a teaching entity. ${ }^{26}$ In 2011, Bury conducted semi-structured interviews with faculty and found that while many faculty members had relied on librarians to teach how to access information, still about eighty percent of them had chosen to teach IL skills themselves. ${ }^{27}$ In 2012, Stanger asked faculty about the importance of collaboration with a librarian to support IL indicators and found that the only area where the support of a librarian was considered great or very great was in designing and implementing search strategies. ${ }^{28}$

Between the 2012 Ithaka Survey and the corresponding 2015 survey, there was a significant upward trend of faculty members' perceived importance of the library's role in undergraduate student research support. ${ }^{29}$ This increase was seen across subject disciplines. The upward trend leveled out in the 2018 survey. ${ }^{30}$ The 2015 Ithaka Survey indicated that faculty members were in agreement that "undergraduate students have poor skills related to locating and evaluating scholarly information and, thus, are in need of improved research, critical analysis, and information literacy skills." ${ }^{31}$ The 2018 survey showed similar findings in this area. ${ }^{32}$ After reading the Ithaka Surveys and other research, we concluded that additional research is needed in relation to undergraduate research skills.

\section{METHODOLOGY}

The primary objectives of this study are as follows:

- Determine if there is a core set of research skills that faculty members expect students to have.

- Better understand TCU faculty expectations and perceptions of undergraduate students' research skills.

- Develop better collaborative teaching relationships and information literacy initiatives.

\section{Focus Groups}

To fulfill these objectives, we decided to hold focus groups with faculty teaching undergraduate students at TCU. This research project was approved by the TCU Institutional Review Board (IRB). To recruit participants for the study, we sent an e-mail to all TCU faculty members and also advertised the study via a university announcement website. These recruitment efforts occurred approximately three weeks before the first focus group.

Ultimately, 21 out of 1,031 (641 full-time and 390 parttime) faculty members who teach undergraduates participated in the focus groups (see table 1). ${ }^{33}$ The three focus groups included six, seven, and eight faculty members, respectively, and occurred in November 2016. We assigned each interested faculty member to a specific focus group based on the faculty member's availability. If the participant was available for more than one timeslot, then we assigned the participant to the group that would result in the broadest subject distribution within each group. Each of the three focus groups contained participants from multiple departments on campus representing a range of ranks.

To prevent any bias, a moderator unaffiliated with the university conducted each focus group. He was selected because he holds both a JD and a PhD in anthropology and has taught at the university level. Additionally, he has 
Table 1. Focus groups: faculty rank and subject discipline distribution

\begin{tabular}{lc}
\hline Rank & \# of participants \\
Professor & 6 \\
Associate professor & 4 \\
Assistant professor & 7 \\
Instructor & 2 \\
Assistant instructor & 1 \\
Adjunct professor & 1 \\
Discipline & \# participants \\
Liberal Arts & 7 \\
Science \& Engineering & 7 \\
Fine Arts & 3 \\
Nursing \& Health Sciences & 3 \\
Communication & 1 \\
\hline
\end{tabular}

extensive professional training in focus group moderation and has facilitated focus groups and ideation sessions for universities. In preparation for the focus groups, we prepared a written guide (see appendix A) of several questions for the moderator to ask. After a brief introduction, the written guide suggested 20 minutes of questions about the role of student research in the course curriculum, 25 minutes of questions about expectations and perceptions of student research skills, 15 minutes on tools for developing student research skills, and a short brainstorming session. The focus groups concluded with a brief moderator-led wrap-up.

During the focus groups, the moderator could ask other related questions and lead the discussion as he saw fit. We viewed the focus groups via a one-way mirror and recorded the audio of the sessions. Afterwards, we transcribed the recordings. We separated out each focus group comment and then organized all comments into themes based on our original research questions and other topics.

\section{Survey}

After processing all data from the focus groups, we decided to explore the research issues further and especially wanted additional information about faculty perceptions and expectations of undergraduate student skills. To accomplish this, we implemented a survey using Qualtrics (see appendix B). We gained approval from the IRB to create the survey and then performed a pilot with a group of three faculty members. In October 2017, we sent the survey via e-mail to all 669 full-time and 351 part-time faculty members with a two-week completion deadline. ${ }^{34}$ Each faculty member who completed the survey was eligible to enter a random drawing for a prize. Altogether, 100 faculty members participated in the survey. The first question asked the participants whether they teach undergraduate students, and the survey ended immediately for those who answered "No." There were 91 participants who answered "Yes," and those persons continued with the remainder of the survey.

The survey contained both multiple-choice and openended response questions. For each multiple-choice question, we randomized the order of the answer choices; however, when the same choices were presented for consecutive questions, we kept the same order for that participant. We were particularly interested in breaking down faculty responses into their perceptions of upper-level (junior/ senior) and lower-level (freshman/sophomore) student groups and tailored some questions to target this distinction. Because participants were free to skip most questions or exit the survey at any time, the number of responses varied from question to question.

We used knowledge gained from the focus groups in constructing the questions. More specifically, after coding the focus group transcripts, we identified several frequently mentioned research skills, which became the basis of several questions at the heart of the survey. We also asked a number of questions that served to classify the participants' responses. Based on their answers to these questions, other questions displayed to certain participants. After the survey deadline, we coded the data received from the open-ended survey questions and began to analyze all the data to identify important trends and other findings.

\section{FINDINGS}

\section{Core Research Skills Identified by Faculty Members}

Based on the most frequent responses from the faculty focus groups, we identified several student skills related to research. We organized these into categories. We will call these the nine core skills for the remainder of this study. We used these skills as the basis for many of the survey questions. The nine core skills (see appendix $\mathrm{C}$ ) are as follows:

- Topic selection

- Search strategy

- Finding resources

- Differentiating source types

- Evaluating sources

- Synthesizing information

- Summarizing information

- Citing sources

- Reading and understanding citations

\section{Additional Skills}

In addition to the nine core skills used for the survey, focus group participants mentioned other skills, both directly related to research and not. For example, focus group participants mentioned critical thinking. We considered including this in our core group of skills for the survey; however, given 


\section{FEATURE}

that critical thinking " is a highly contentious skill in that researchers debate about its definition; its amenability to assessment; its degree of generality or specificity; and the evidence of its practical impact," we decided not to include it. ${ }^{35}$ Some faculty members mentioned confirmation bias but not enough to merit inclusion in the core group of skills for the survey. Other skills that one or two focus group participants mentioned included reading skills, writing skills, time management skills, and work ethic. We did not include these in our final core skill set because they were rarely mentioned, and most of these might be better described as life skills or study skills.

\section{Faculty Perceptions and Expectations of Student Skills}

We presented several survey questions that related to faculty perceptions and expectations of students' research and information skills. We asked which of the nine core skills they expect students to possess at the beginning and end of their undergraduate college career (see figure 1). Of the 84 participants that responded to this question, a majority expect incoming students to possess these three skills: summarizing information (80\%), finding resources (67\%), and search strategy (60\%). Upon graduation, a majority of faculty members expect that students will possess eight of the nine skills examined in this study. The only core skill not selected by a majority of faculty was summarizing information (46\%). This actually represents a decrease in faculty expectations for student skills and might indicate some confusion by survey participants. The highest scoring skills selected by faculty for the graduation timeframe were evaluating sources (86\%) and synthesizing information (82\%).

We asked faculty to rate their students' abilities to perform the nine core skills. We asked this separately for lowerlevel and upper-level students (see figure 2). The question for each level was only asked of those faculty members who indicated that they teach students at that particular level. Using a Likert-type scale, faculty members could select one of five possible responses ranging from "Completely capable" to "Not at all capable." For participants who responded about lower-level students ( $n=34)$, there was a tie for the highest rated skill between finding resources and summarizing
What information or research skills should undergraduate students possess at the following times? Percentage of faculty selecting each skill.

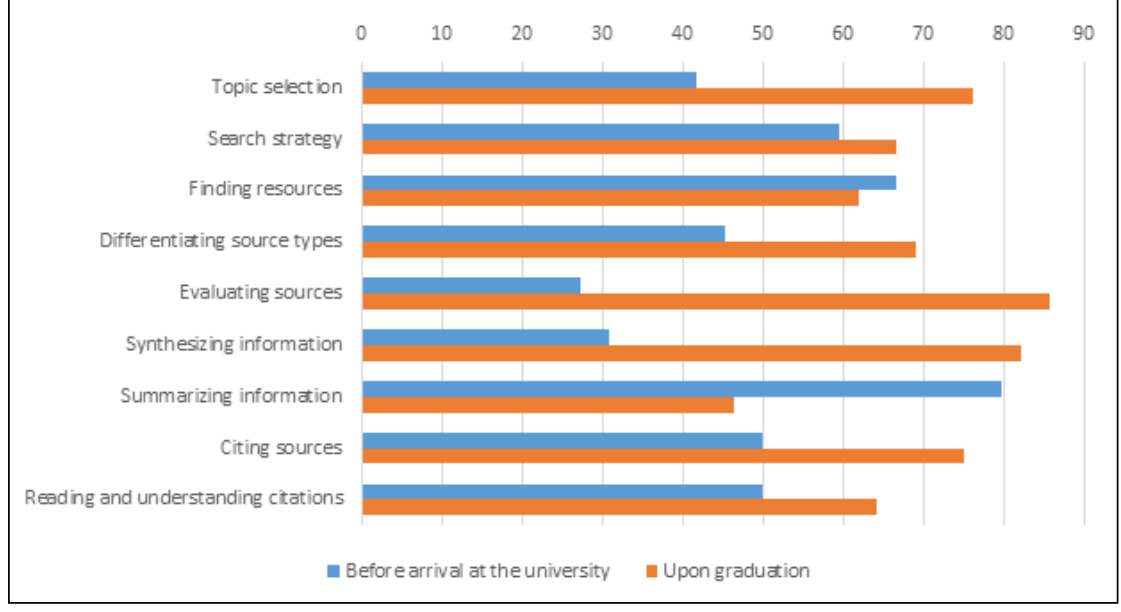

Figure 1. Faculty expectations of information skills before arrival at college and at time of graduation

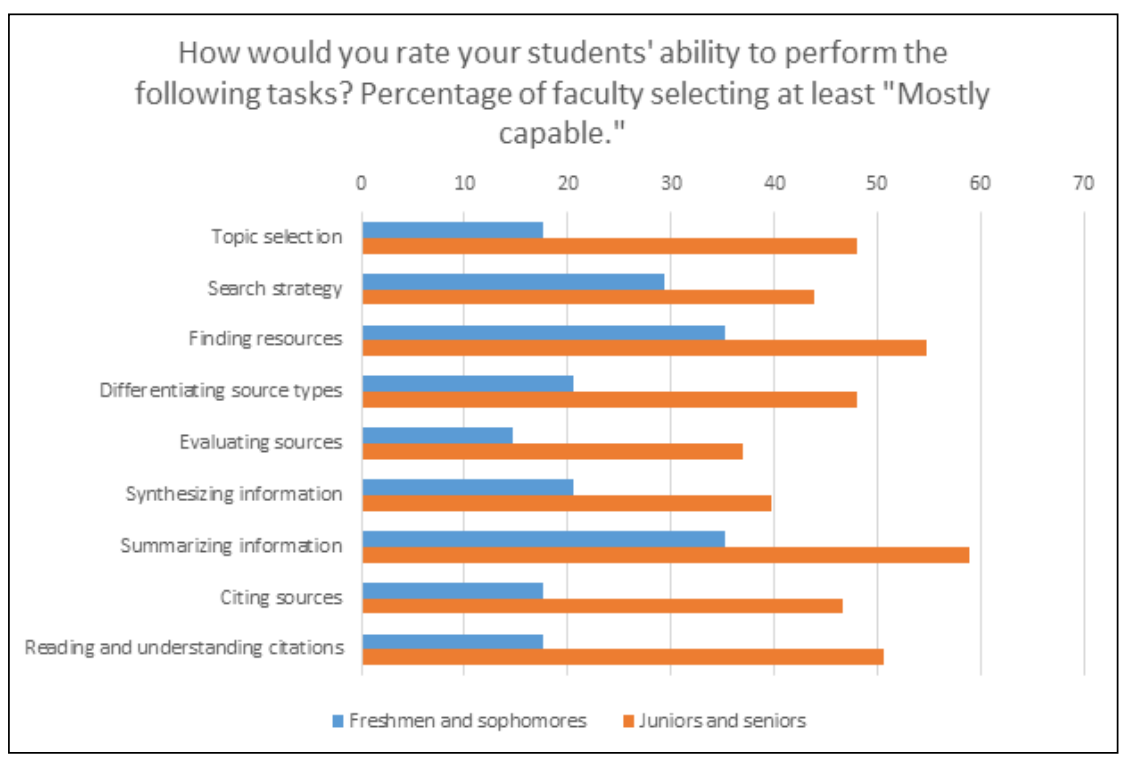

Figure 2. Faculty rating of students' ability to perform tasks

information (35.3\%), based on the summation of the number of completely capable and mostly capable responses. Using the same basis, the lowest rated skill was evaluating sources (15\%). For participants who answered about upper-level students ( $n=73)$, summarizing information was the highest rated skill (59\%). The lowest continued to be evaluating sources (37\%).

We also included an open-ended text box question asking which research skills are most lacking among undergraduate students. After we coded the responses $(n=87)$ into categories, we found that the most common responses mentioned the following topics: evaluating sources (30\%), critical thinking (29\%), and finding resources (26\%). One 
Table 2. Number of faculty selecting option shown when asked "In your opinion, who should have primary responsibility for teaching these research skills?"

\begin{tabular}{|c|c|c|c|c|}
\hline Skill & Professor & Librarian & $\begin{array}{l}\text { Joint effort } \\
\text { (Professor- } \\
\text { Librarian) }\end{array}$ & Student self-teach \\
\hline Topic selection/formation and scope & 51 & 1 & 24 & 4 \\
\hline Search strategy & 3 & 32 & 36 & 9 \\
\hline Finding resources online/in print & 3 & 30 & 42 & 5 \\
\hline Differentiating source types & 20 & 10 & 45 & 5 \\
\hline Evaluating sources & 27 & 3 & 48 & 2 \\
\hline Synthesizing information & 59 & 0 & 7 & 14 \\
\hline Summarizing information & 49 & 0 & 8 & 23 \\
\hline Citing sources & 34 & 4 & 31 & 11 \\
\hline Reading and understanding citations & 22 & 9 & 37 & 12 \\
\hline
\end{tabular}

salient quote was "Actually reading material, processing it, and thinking critically about it is something most undergrads don't seem to know how to do."

In the focus groups, faculty members perceived students as not understanding the bigger picture or why they are learning a concept. Faculty members also mentioned the idea of students often being motivated by grades more than learning. One faculty member commented that "the mindset of the student is to finish the assignment . . . as opposed to 'I'm going to learn about this area." We also heard from faculty that students want to do research assignments backward. For example, some students draw their conclusions first and then look for research to support their conclusion, as opposed to researching a topic and drawing a conclusion organically.

\section{Collaborative Teaching Relationships and Information Literacy}

We asked faculty to identify who should have the primary responsibility to teach the nine core skills, and 80 responded to this question (see table 2). None of the skills received a majority of responses for librarian alone as the primary party to teach a skill. The highest percentage that librarian attained for any one skill was 40 percent for search strategy, followed by 38 percent for finding resources. When the responses for librarian and joint effort were added together, finding resources (90\%) was selected the most, followed by search strategy (85\%).

We then asked a related question. For those skills where the participant selected either librarian or joint effort, we asked faculty what would be the best way for a librarian to teach those skills. This multiple-choice question had five responses plus an "Other" choice. Of the 77 faculty members who answered this question, the most frequently selected response was inviting a librarian to the professor's class to work on a particular assignment or skill (26\%).

We asked survey participants whether they had invited a librarian to their classes, and of the 79 faculty members that responded to this question, 59 percent had. For those who answered "Yes," we gave a follow-up question with a text box, asking what aspect was the most beneficial within the instruction session. We received many answers, but the most common themes were having an opportunity to meet the librarian face-to-face and learning about library resources. On this topic in the focus groups, one faculty member mentioned that "the greatest thing [the librarian] does is give them a name, a face, and a sense of approachability." Another said that the librarian possessed "expertise that I don't have... I know how to do research, but I don't know how to teach it effectively in a 50- or 80-minute class." Some faculty members even mentioned that they themselves learned from the librarian about new resources or specific aspects of searching different databases during these sessions.

Similarly, for survey participants that answered "No" (41\%) to the above question, we asked what was preventing them from using library instruction. We gave two possible responses, which were "I was not aware of this service" and "Other" with a text box. Nearly half indicated that they were not aware of this service. The "Other" responses included time constraints and not considering library instruction to be pertinent to their particular class. On this topic in the focus groups, faculty members mentioned a scarcity of class time being a reason that they did not invite a librarian to class. Faculty members also mentioned that in some cases, they wished to teach the content themselves. In addition, there was also a concern about repeated content in library instruction over a student's career.

We then asked faculty how the library can help improve student research skills to better meet faculty expectations. This was a free-form text box, and we received a wide variety of answers $(n=78)$. The most common two suggestions from the faculty survey were for librarians to teach research skills such as finding, evaluating, and citing sources and to have online tutorials and webinars. The third-most mentioned suggestion was having one-on-one consultations. In the focus groups, some suggestions that faculty members offered 


\section{FEATURE}

were to increase the presence of librarians in departmental buildings, to use librarians more in introductory classes, and to include librarians at faculty orientation events. In the focus group brainstorming exercise, the participants indicated that it was important to integrate librarians at all levels of the student's college career.

\section{DISCUSSION}

\section{Implications for Our IL Program}

The survey results established that faculty members viewed themselves as having the primary role in teaching most of these skills. We were encouraged to see the high number of faculty members who see librarians as having at least some role in teaching almost all of the nine core skills. However, it is discouraging that a large number of faculty members remain unaware of the availability and capability of librarians to teach information skills. Perhaps we need to reconsider our marketing strategies related to IL instruction. We are pleased that those faculty members who do use IL instruction from librarians are highly appreciative of the librarians and their capabilities.

Furthermore, the fact that faculty mentioned having an issue with repeated content in library instruction over the course of a student's career may lead us to consider structural changes in the way we teach these skills. How might we integrate and scaffold library instruction into the overall undergraduate curriculum in such a way that all students will learn this important information, yet not have a high level of repetition?

\section{Scaffolding Skills}

Many studies have shown that faculty members generally agree on the importance of IL skills. ${ }^{36}$ Our findings also demonstrate this disposition. In the survey, faculty members see progress from freshmen/sophomore to junior/senior level students' research skills in all nine core skill areas. When asked about how a student's ability to find information grows over time, one of our focus group participants stated, "Not just [the] ability to find, but ability to know what is quality information!" Examining these findings, a librarian or a faculty member can gain an understanding of which skills an undergraduate student develops at which times during their years in college. This can guide the development of an instruction session or assignment related to IL. In a larger sense, this can lead to the development of a scaffolded series of assignments, IL sessions, or courses over a four-year undergraduate curriculum. We hope that this leads to conversations between librarians and faculty about how best to engage in curriculum planning.

\section{Relationship with the ACRL Framework}

Looking at ACRL's Framework for Information Literacy for Higher Education, we were able to produce a crosswalk (see table 3) between the nine core skills and the six frames that the Framework outlines to assist librarians with creating more cohesive IL curricula. ${ }^{37}$ When we aligned the nine core skills with the Framework, we also noticed that several of the nine core skills fall into more than one frame, which is expected given the frames' inter-relational nature. On the flipside, we concluded that all Framework frames are covered by the nine core skills.

\section{Comparisons to the Literature}

The 2013 Dubicki study indicates that faculty perceive "evaluating and critically assessing the information" to be the most important IL skill. ${ }^{38}$ Our study concurs with Dubicki, showing that evaluating sources is the skill that faculty expect at the highest level for students at graduation. When asked about the actual student skill level, Dubicki finds "evaluating and critically assessing the information" to be the weakest of the skills students possess. ${ }^{39}$ Our study agrees in regards to faculty perceptions of evaluating sources for both upper-level and lower-level students.

We also noticed a concurrence with the 2012 Stanger article. The Stanger study showed that faculty valued the librarian most when designing and implementing search strategies. ${ }^{40}$ In our study, faculty perceived search strategy to be the skill for which librarians should have the highest primary responsibility. 


\section{Limitations}

For both the focus groups and survey, faculty members at TCU could choose whether to participate. This self-selection may have produced a biased sample, including bias by subject discipline and pre-existing attitudes or behaviors related to the library and specific library staff. Additionally, it is possible that some faculty members participated in both the focus group and the survey.

\section{CONCLUSIONS}

The research presented in this paper used focus group transcript analysis to identify a set of nine core skills critical to the research process that faculty members at TCU expect students to master. The follow-up anonymous survey provided insight that our students are improving in these skills over the course of their college career but do not necessarily attain full mastery as upper-level (junior/senior) students.

Our work demonstrated that faculty members talk about the important components of the research process with a vocabulary that is different from the terms used in the Framework. However, as shown by the mapping of the skills to the various frames, the underlying concepts and abilities are the same. In marketing our services to faculty, we should be cognizant of this difference in language.

An additional takeaway from this study is motivation to increase the avenues through which librarians have contact with faculty and students. This may benefit IL, reference, and other duties common to subject liaison librarians. For example, we hope to have an increased presence in departmental buildings. Another example is the need for an increased presence in our university's course management system. Our increased visibility in the CMS could be an early foundational step towards constructing a comprehensive IL online course.

Mastery of the skills involved in exploring a problem and potential solutions to that problem is a critical life skill. In today's "information overload" environment, the library continues to have a key role in helping students develop this foundational capability. Well-educated students can become life-long learners, contributing to their community and society in general.

We currently have a committee reviewing the data from the study to identify gaps between the library's current practices and faculty expectations. This committee will ultimately make recommendations for programmatic changes. We also recognize that additional directions for further research include understanding library-related or library-adjacent skills such as critical reading or writing. Lastly, we conclude that there are great opportunities to explore the nine core skills in greater detail, including understanding how faculty and students in various subject disciplines differ in their attitudes and behaviors with respect to each of the skills.

\section{ACKNOWLEDGEMENT}

The authors would like to acknowledge the following librarians at Texas Christian University for their contributions to this project: Diana Boerner, Business Librarian, for her help with the focus groups and the beginning stages of survey development; and Alysha Sapp, Nursing and Nurse Anesthesia Librarian, for her help with the focus groups.

\section{REFERENCES}

1. Texas Christian University, "Quick Reference Fall 2018," accessed January 30, 2019, http://www.ir.tcu.edu/zfiles/Fall2018.pdf.

2. Paul G. Zurkowski, "The Information Service Environment: Relationships and Priorities, Related Paper No. 5," 1974, accessed November 14, 2018, http://files.eric.ed.gov/fulltext /ED100391.pdf.

3. Association of College \& Research Libraries, Information Literacy Competency Standards for Higher Education (Chicago: American Library Association, 2000), https://alair.ala.org/handle /11213/7668.

4. Association of College and Research Libraries, Framework for Information Literacy for Higher Education (Chicago: American Library Association, 2015), accessed November 14, 2018, http:// www.ala.org/acrl/standards/ilframework.

5. Carol C. Kuhlthau, "Developing a Model of the Library Search Process: Cognitive and Affective Aspects," Reference Quarterly 28, no. 2 (1988): 232-42.

6. Christine Bruce, The Seven Faces of Information Literacy (Adelaide, Australia: Auslib Press, 1997), 40.

7. Bruce, The Seven Faces of Information Literacy, 114.

8. Michael B. Eisenberg and Robert E. Berkowitz, "Information Problem-Solving: The Big Six Skills Approach," School Library Media Activities Monthly 8, no. 5 (1992): 27-42.

9. Eleonora Dubicki, "Faculty Perceptions of Students' Information Literacy Skills Competencies," Journal of Information Literacy 7 , no. 2 (2013): 97-125.

10. Jonathan Cope and Jesús E. Sanabria, "Do We Speak the Same Language? A Study of Faculty Perceptions of Information Literacy," Portal: Libraries and the Academy 14, no. 4 (2014): 475-501.

11. Keith Stanger, "Whose Hands Ply the Strands? Survey of Eastern Michigan University Psychology Faculty Regarding Faculty and Librarian Roles in Nurturing Psychology Information Literacy," Behavioral E Social Sciences Librarian 31, no. 2 (2012): 112-27.

12. Laura Saunders, "Faculty Perspectives on Information Literacy as a Student Learning Outcome," The Journal of Academic Librarianship 38, no. 4 (2012): 226-36.

13. Anna Yevelson-Shorsher and Jenny Bronstein, "Three Perspectives on Information Literacy in Academia: Talking to Librarians, Faculty, and Students," College $E$ Research Libraries 79, no. 4 (2018): 535-53.

14. Patricia F. Vander Meer, Maria A. Perez-Stable, and Dianna E. Sachs, "Framing a Strategy: Exploring Faculty Attitudes toward Library Instruction and Technology Preferences to Enhance Information Literacy," Reference \& User Services Quarterly 52, no. 2 (2012): 109-22, https://doi.org/10.5860/rusq.52n2.109.

15. Sophie Bury, "Faculty Attitudes, Perceptions and Experiences of Information Literacy: A Study across Multiple Disciplines at York University, Canada," Journal of Information Literacy 5, no. 1 (2011): 45-64.

16. Sophie Bury, "Learning from Faculty Voices on Information Literacy: Opportunities and Challenges for Undergraduate Information Literacy Education," Reference Services Review 44, no. 3 (2016): 237-52. 


\section{FEATURE}

17. Shelley Gullikson, "Faculty Perceptions of ACRL's Information Literacy Competency Standards for Higher Education," The Journal of Academic Librarianship 32, no. 6 (2006): 583-92.

18. Christine Wolff-Eisenberg, Alisa B. Rod, and Roger C. Schonfeld, "Ithaka S+R US Faculty Survey 2015," Ithaka S+R, April 4, 2016, https://sr.ithaka.org/publications/ithaka-sr-us-faculty -survey-2015/.

19. Heather B. Perry, "Information Literacy in the Sciences: Faculty Perception of Undergraduate Student Skill," College E Research Libraries 78, no. 7 (2017): 964-77.

20. Yuhfen D. Wu and Susan L. Kendall, "Teaching Faculty's Perspectives on Business Information Literacy," Reference Services Review 34, no. 1 (2006): 86-96.

21. Gullikson, "Faculty Perceptions," 589.

22. Gloria J. Leckie and Anne Fullerton, "Information Literacy in Science and Engineering Undergraduate Education: Faculty Attitudes and Pedagogical Practices," College \& Research Libraries 60, no. 1 (1999): 9-29.

23. Saunders, "Faculty Perspectives," 232.

24. William Badke, "Why Information Literacy is Invisible," Communications in Information Literacy 4, no. 2 (2011): 129-41.

25. Gaby Divay, Ada M. Ducas, and Nicole Michaud-Oystryk, "Faculty Perceptions of Librarians at the University of Manitoba," College \& Research Libraries 48, no. 1 (1987): 27-35.

26. Ada M. Ducas and Nicole Michaud-Oystryk, "Toward a New Venture: Building Partnerships with Faculty," College \& Research Libraries 65, no. 4 (2004): 334-48.

\section{APPENDIX A. FOCUS GROUP QUESTIONS}

\section{Objectives}

1. Better understand TCU faculty expectations for and perceptions of undergraduate students' research skills.

2. Determine if there is a core set of research skills that faculty members expect students to have.

3. Develop better collaborative teaching relationships and information literacy initiatives.

\section{Introduction: 5 min}

- Thank you for joining us today. My name is Chris McCollum, and I am an independent moderator. You're here because TCU Library needs your help in better understanding the research skills of undergraduate students so that they, the library, can better meet your needs and expectations.

- For our discussion today, let's steer away from the topic of empirical research, but otherwise, I'd like you to talk about whatever comes to mind when you think of "student research."

- As we move through our discussion, we will talk about the role that undergraduate research skills play in your classes, as well as the strengths/weaknesses that you perceive in these skills.

- As we share ideas, remember that we are interested in gathering a wide range of opinions (both positive and negative) and are NOT trying to achieve consensus.

- Very important that we turn of cell phones, speak one at a time, avoid side conversations, and have fun!
27. Bury, "Learning from Faculty," 237-52

28. Stanger, "Whose Hands," 119.

29. Roger Schonfeld and Ross Housewright, "US Faculty Survey 2012," Ithaka S+R, April 8, 2013, https://sr.ithaka.org/publica tions/us-faculty-survey-2012/; Wolff-Eisenberg et al., "Ithaka S+R US Faculty Survey 2015."

30. Melissa Blankstein and Christine Wolff-Eisenberg, "Ithaka S+R US Faculty Survey 2018," Ithaka $S+R$, April 12, 2019, accessed December 1, 2019, https://doi.org/10.18665/sr.311199.

31. Wolff-Eisenberg et al., "Ithaka S+R US Faculty Survey 2015."

32. Blankstein and Wolff-Eisenberg, "Ithaka S+R US Faculty Survey 2018."

33. Texas Christian University, "Quick Reference Fall 2016," accessed December 1, 2019, http://www.ir.tcu.edu/zfiles/Fall2016.pdf.

34. Texas Christian University, "Quick Reference Fall 2017," accessed December 1, 2019, http://www.ir.tcu.edu/zfiles/Fall2017.pdf.

35. Ou Lydia Liu, Lois Frankel, and Katrina Crotts Roohr, "Assessing Critical Thinking in Higher Education: Current State and Directions for Next-Generation Assessment," ETS Research Report Series 2014, no. 1 (2014): 1-23.

36. Examples include Dubicki, "Faculty Perceptions"; Saunders, "Faculty Perspectives"; Bury, "Faculty Attitudes."

37. Association of College \& Research Libraries, Framework.

38. Dubicki, "Faculty Perceptions," 103.

39. Dubicki, "Faculty Perceptions," 107.

40. Stanger, "Whose Hands," 119.

- Collect homework

- Please write your first name at the top of your pad of paper. You can use this to write down any thoughts you have that you didn't get a chance to share with group.

- Any questions before we get started?

Let's start with an introduction so that we can get to know each other a little better:

- Tell us:

- Name/department/weekend for fun

\section{Role of Student Research in Curriculum: 20 min}

1. How often do you use research assignments in your undergraduate classes? (PROBE: reasons for using or not)

- How does this differ, if at all from when you first started teaching?

2. What types of research assignments do you use?

- How do you decide on a topic? (PROBE: Personal interest? Student interest? Other?)

- What type(s) of research assignments do you avoid using, and why?

- To what extent do you consider the level of students (upperclassmen vs. underclassmen) when deciding to use a particular research assignment?

- How (if at all) do you vary research assignments based on level? 
- Which type(s) of assignments work well with first year students?

o Which type(s) work well with upperclassmen?

3. Describe a typical assignment (PROBE: how structured-components/steps/scaffolding)

- Do you research topic beforehand?

- Do you specify which resources students should and/ or should not use? (List resources and probe reasons for encouraging/discouraging use)

- To what extent do you check/verify citations? (PROBE: frequency and methods)

4. What skills or knowledge do you hope students will learn from your research assignments? (List on whiteboard)

- How do your assignments help students develop each of these skills? (PROBE: which components/steps teach which skills?)

\section{Expectations for, and Perceptions of Students' Research Skills: 25 min}

5. Overall, how well do your undergraduate students conduct research? (PROBE: underclassmen vs. upperclassmen)

- What impresses you about your students' research skills? (PROBE: what skills they perform well)

- What frustrates you about your students' research skills? (PROBE: what skills they are lacking)

- What are some obstacles/challenges your students face when conducting research?

- How well do they understand the difference between resources, such as magazine vs. newspaper vs. journal?

- How have your students' research skills changed over the years?

6. How would you rate your students' ability to find quality information-scale of 1 to 10 ? ( 1 is poor and 10 is excellent; go around and mark each participant's score)

- Reasons for rating high or low

- What does the "quality information" mean to you?

7. How would you rate your students' ability to evaluate the reliability/credibility of resources-scale of 1 to 10 ? ( 1 is poor and 10 is excellent; go around and mark each participant's score)

- Reasons for rating high or low

8. What research skills do you expect students to have when they arrive at TCU as first years? (List on whiteboard)

- How successfully do your first-year students demonstrate these skills? (PROBE expectation/performance gap)

- Which skill is most essential to learn before they arrive at TCU?

- Which research concepts are the most challenging for your first years to learn and understand?

9. What research skills do you expect TCU students to develop by the time they graduate? (List on whiteboard)

- How successfully do your seniors demonstrate these research skills? (PROBE expectation/performance gap) - Which skill is most essential for students to learn before they leave TCU?

- Which research concepts are challenging for even your seniors to learn and understand?

\section{Tools for Developing Research Skills: 15 min}

10. To what extent do you teach specific research method(s) to your students? (PROBE: specific methods/techniques)

- Which classes/students?

- How successful is this approach in developing your students' research skills? (PROBE: which skills)

11. How often do you direct your students to specific library resources?

- Which resources?

- Which classes/students?

- How successful is this approach in developing your students' research skills? (PROBE: which skills)

12. How, if at all do you use librarians to teach research skills to your students?

- Reasons for using librarian? (PROBE: benefits, enablers)

- Reasons for not using librarian? (PROBE: obstacles, drawbacks)

13. Which research skills, if any, do you believe you, as a professor, should directly teach your students?

14. Which research skills, if any, do you believe a librarian should be responsible for teaching your students?

15. Which research skills, if any, do you believe students should be responsible for teaching themselves?

\section{Brainstorm: How to Improve Students' Research Skills: 5 min}

16. Write down (on your pad of paper) as many ideas as you can for ways to improve undergraduate research skills. This is a "brain dump" exercise- so don't worry about whether an idea is realistic or practical, or even a "good" idea. I will only give you two minutes for this first stage-GO! (2 min) (Moderator goes around and encourages/assists individuals as necessary)

17. STOP! Now, go through your ideas and select your BEST idea and circle it on the page. (1 min)

18. Who had an idea he/she would like to share with the group. (3 min) 


\section{FEATURE}

\section{APPENDIX B. FACULTY LIBRARY INSTRUCTION SURVEY}

[Author note: The appearance of some questions was dependent on the answers to prior questions in the survey.]

Thank you for participating in this survey about Faculty Expectations and Perceptions of Undergraduate Students' Research Skills. The survey is anonymous and will take approximately 10 minutes to complete. Taking part in this survey is completely voluntary. Clicking the "Next" button indicates your consent to participate. You may choose to terminate the survey before completing it without any adverse (Next) effects. If you have any questions about this survey, please contact Boglarka Huddleston, principal investigator, at (817) 257-6063 or b.huddleston@tcu.edu. After completing the survey, you will have a chance to enter a drawing for a gift basket. Any personal information gathered for the drawing will be kept separately from the survey; your response will not be connected to your answers to the survey questions.

For the purpose of this survey, the definition of "research" is as follows: An investigation or experimentation aimed at the discovery and interpretation of facts, e.g., collecting information about a particular subject; completing a literature review; using the internet, databases and other library resources to find articles to support an argument; etc.

Do you teach undergraduate classes?

( ) Yes ( ) No

Do you include a research assignment in any of your classes?

Freshman/Sophomore: ( ) Yes ( ) No ( ) Not Applicable

Junior/Senior: ～( ) Yes ( ) No ( ) Not Applicable

What is the main reason you include a research assignment?

( ) It teaches critical thinking

( ) Students learn more about the topic

( ) Helps to integrate student learning

( ) Students discover something new

( ) Other, please specify

What is the main reason you do not include a research assignment?

( ) Time constraints

( ) Subject does not lend itself to research-type assignment

( ) Trying to navigate research resources is too complicated (for students)

( ) Students do not know how to do research

( ) Other, please specify

What one essential information/research skill is most deficient among undergraduate students?

What information or research skills should undergraduate students possess at the following times? Please mark all that apply.

Topic selection/formation and scope (narrowing, broadening)

Before arrival at TCU

Search strategy (keywords, combining keywords, etc.)

Finding resources online/in print

Differentiating among types of sources (primary, secondary, etc.)

Evaluating sources (credibility, reliability, etc.)

Synthesizing information

Summarizing information

Properly citing sources

Reading and understanding citations

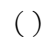

Upon graduation from TCU

What other information or research skills are important for students to learn? 
How would you rate your freshmen/sophomore students' ability to perform the following research tasks?

\begin{tabular}{|c|c|c|c|c|c|}
\hline & $\begin{array}{l}\text { Completely } \\
\text { capable }\end{array}$ & $\begin{array}{l}\text { Mostly } \\
\text { capable }\end{array}$ & $\begin{array}{l}\text { Somewhat } \\
\text { capable }\end{array}$ & $\begin{array}{l}\text { Minimally } \\
\text { capable }\end{array}$ & $\begin{array}{l}\text { Not at all } \\
\text { capable }\end{array}$ \\
\hline $\begin{array}{l}\text { Topic selection/formation and scope (narrowing, } \\
\text { broadening) }\end{array}$ & ( ) & ( ) & ( ) & $($ ) & $($ ) \\
\hline Search strategy (keywords, combining keywords, etc.) & ( ) & ( ) & ( ) & ( ) & $($ ) \\
\hline Finding resources online/in print & ( ) & ( ) & ( ) & ( ) & $($ ) \\
\hline $\begin{array}{l}\text { Differentiating among types of sources (primary, } \\
\text { secondary, etc.) }\end{array}$ & ( ) & ( ) & ( ) & ( ) & $($ ) \\
\hline Evaluating sources (credibility, reliability, etc.) & ( ) & ( ) & ( ) & ( ) & $($ ) \\
\hline Synthesizing information & ( ) & ( ) & ( ) & ( ) & $($ ) \\
\hline Summarizing information & ( ) & ( ) & ( ) & ( ) & ( ) \\
\hline Properly citing sources & ( ) & ( ) & ( ) & ( ) & $($ ) \\
\hline Reading and understanding citations & ( ) & ( ) & ( ) & $($ ) & $($ ) \\
\hline
\end{tabular}

How would you rate your junior/senior students' ability to perform the following research tasks?

\begin{tabular}{|c|c|c|c|c|c|}
\hline & $\begin{array}{l}\text { Completely } \\
\text { capable }\end{array}$ & $\begin{array}{l}\text { Mostly } \\
\text { capable }\end{array}$ & $\begin{array}{l}\text { Somewhat } \\
\text { capable }\end{array}$ & $\begin{array}{l}\text { Minimally } \\
\text { capable }\end{array}$ & $\begin{array}{l}\text { Not at all } \\
\text { capable }\end{array}$ \\
\hline $\begin{array}{l}\text { Topic selection/formation and scope (narrowing, } \\
\text { broadening) }\end{array}$ & ( ) & ( ) & ( ) & ( ) & ( ) \\
\hline Search strategy (keywords, combining keywords, etc.) & ( ) & ( ) & $($ ) & ( ) & ( ) \\
\hline Finding resources online/in print & () & ( ) & $($ ) & ( ) & ( ) \\
\hline $\begin{array}{l}\text { Differentiating among types of sources (primary, } \\
\text { secondary, etc.) }\end{array}$ & ( ) & ( ) & ( ) & ( ) & () \\
\hline Evaluating sources (credibility, reliability, etc.) & ( ) & ( ) & $($ ) & $($ ) & $($ ) \\
\hline Synthesizing information & ( ) & ( ) & ( ) & $($ ) & () \\
\hline Summarizing information & ( ) & ( ) & $($ ) & ( ) & () \\
\hline Properly citing sources & ( ) & $($ ) & ( ) & ( ) & ( ) \\
\hline Reading and understanding citations & ( ) & ( ) & ( ) & ( ) & $($ ) \\
\hline \multicolumn{6}{|c|}{ In your opinion, who should have primary responsibility for teaching these research skills? } \\
\hline & \multicolumn{4}{|c|}{$\begin{array}{l}\text { Joint effort } \\
\text { (Professor- } \\
\text { Librarian) }\end{array}$} & $\begin{array}{c}\text { Student } \\
\text { self-teach } \\
\text { (Independent } \\
\text { development) }\end{array}$ \\
\hline $\begin{array}{l}\text { Topic selection/formation and scope (narrowing, } \\
\text { broadening) }\end{array}$ & ( ) & \multicolumn{2}{|l|}{ ( ) } & ( ) & ( ) \\
\hline Search strategy (keywords, combining keywords, etc.) & ( ) & \multicolumn{2}{|l|}{ ( ) } & ( ) & $($ ) \\
\hline Finding resources online/in print & ( ) & \multicolumn{2}{|l|}{ ( ) } & ( ) & $($ ) \\
\hline $\begin{array}{l}\text { Differentiating among types of sources (primary, } \\
\text { secondary, etc.) }\end{array}$ & ( ) & \multicolumn{2}{|l|}{ ( ) } & ( ) & $($ ) \\
\hline Evaluating sources (credibility, reliability, etc.) & ( ) & \multicolumn{2}{|l|}{ ( ) } & ( ) & $($ ) \\
\hline Synthesizing information & ( ) & \multicolumn{2}{|l|}{ ( ) } & ( ) & $($ ) \\
\hline Summarizing information & ( ) & \multicolumn{2}{|l|}{ ( ) } & ( ) & $($ ) \\
\hline Properly citing sources & ( ) & \multicolumn{2}{|l|}{ ( ) } & ( ) & $($ ) \\
\hline Reading and understanding citations & () & \multicolumn{2}{|l|}{ ( ) } & () & () \\
\hline
\end{tabular}




\section{FEATURE}

For the skills that you selected "librarian" or "joint" on the previous question, what is the best way for a librarian to teach those skills?

( ) Librarian teaches as part of basic-level class (e.g., English comp)

( ) Create a for-credit course on research skills/information literacy

( ) Professor invites librarian to class to work on a particular assignment/skill

( ) Librarian-developed web-based tutorial

( ) Individual librarian-student consultation

( ) Other ways librarians can teach these skills:

In the past, have you invited a librarian into your class to teach research skills to students?

( ) Yes ( ) No

What was the most beneficial aspect of this instruction session?

What's preventing you from using library instruction?

( ) I was not aware of this service.

( ) Other, please specify:

How can the library help improve student research skills to better meet your expectations? Please include as much detail as possible:

\section{APPENDIX C. ABBREVIATED SKILL NAMES}

This table provides clarification on referring to the nine core skills in this document. The left-hand column shows how the nine core skills appeared in the faculty survey; the right-hand column shows how the nine core skills are referenced throughout this article.

\section{Faculty survey}

Topic selection/formation and scope (narrowing, broadening)

Search strategy (keywords, combining keyword, etc.)

Finding resources online/in print

Differentiating among types of sources (primary, secondary, etc.)

Evaluating sources (credibility, reliability, etc.)

Synthesizing information

Summarizing information

Properly citing sources

Reading and understanding citations

\section{Article}

Topic selection

Search strategy

Finding resources

Differentiating source types

Evaluating sources

Synthesizing information

Summarizing information

Citing sources

Reading and understanding citations 